\title{
Współpraca międzynarodowa miasta na prawach powiatu. Przykład Płocka ${ }^{2}$
}

\begin{abstract}
Streszczenie
Artykuł ten stanowi studium przypadku i przedstawia współpracę międzynarodową jednego z 66 polskich miast na prawach powiatu - Płocka, miasta przeciętnej wielkości w tej kategorii polskich samorządów terytorialnych, które jednak nie jest przeciętne pod względem tradycji historycznych. Było ono przez kilkadziesiąt lat stolicą Polski i historyczną stolicą jednej z jej dzielnic - Mazowsza. Dzisiaj jest miastem średniej wielkości, które bardzo aktywnie działa na arenie międzynarodowej. Za współpracę międzynarodową zostało wyróżnione wieloma nagrodami Rady Europy: Dyplomem Europejskim, Flagą Honorową i Tablicą Honorową. Artykuł przedstawia działalność Płocka, która doprowadziła do otrzymania tych wyróżnień.
\end{abstract}

Słowa kluczowe: Płock, samorząd terytorialny, współpraca międzynarodowa, miasto, powiat, gmina

DOI: $10.33119 / \mathrm{KSzPP} .2019 .3 .6$

\section{International cooperation of a city with the district status. The Płock case study}

\begin{abstract}
This article is a case study that presents the international cooperation of one of the 66 Polish cities with the district status - Płock, a city of average size in this category of Polish local self-governments, which, however, is not average in terms of its historical traditions. For several decades it was the capital of Poland and the historical capital of one of its regions, Mazovia. Today, it is a medium-sized city, which is very active in the international arena. For its international cooperation it has been awarded many Council

1 Wydział Nauk Społecznych, Uniwersytet Przyrodniczo-Humanistyczny w Siedlcach

2 Tekst ma charakter case study. Dlatego nie wymagamy warstwy teoretycznej (red.).
\end{abstract}


of Europe awards: the European Diploma, the Flag of Honour and the Plaque of Honour. This article presents the activities undertaken by the Płock authorities which led to the awarding of these distinctions.

Keywords: Płock, local self-government, international cooperation, city, district, borough

Artykuł stanowi studium przypadku, które dotyczy aktywności międzynarodowej władz samorządowych Płocka oraz wspólnoty lokalnej tego miasta na prawach powiatu. Używa się w nim często określenia „aktywność”, a nie „polityka”. Wynika to z tego, że międzynarodowe działania władz i wspólnoty mieszkańców Płocka są w małym stopniu pochodną głęboko przemyślanych koncepcji, a bardziej wynikiem różnych zbiegów okoliczności. Natomiast jest to polityka publiczna, gdy mamy na myśli realizację/implementację pewnych założeń programowych, jakkolwiek są one słabo skonceptualizowane (Zybała, 2013:28-67). Prowadzenie skonceptualizowanej współpracy zagranicznej jest wśród polskich samorządów terytorialnych rzadkością (Fuksiewicz, Łada, Wenerski, 2012: 5). Zdecydowana większość jednostek samorządu terytorialnego jest aktywna na scenie międzynarodowej w wyniku doraźnych potrzeb i zbiegów okoliczności. Płock jest tutaj typowy, chociaż jego aktywność jest wyjątkowa, co potwierdzają uzyskane za tę działalność nagrody Rady Europy. Warto więc prześledzić jego aktywność na arenie międzynarodowej, która jest osadzona w bogatej tradycji historycznej tego miasta.

Celem artykułu jest opisanie i analiza współpracy międzynarodowej Płocka. Sformułowano konkretne pytania badawcze. Dotyczą one m.in. genezy i ewolucji współpracy międzynarodowej Płocka, jej zróżnicowania, źródeł jej konkretnych kształtów oraz zagadnienia podstawowego: Czy i jak współpraca ta wpływa na wspólnotę obywatelską Płocka?

Źródła, na podstawie których artykuł powstał, pochodzą z płockiego samorządu. Przeprowadzono wywiady z prezydentem miasta, byłym radnym oraz urzędniczką kierującą współpracą międzynarodową miasta Dorotą Bartuś, kierowniczką Referatu Promocji i Współpracy z Zagranicą, która, odpowiadając na przygotowane przez autora pytania, sporządziła specjalne opracowanie. Wykorzystano także notatki płockich urzędników samorządowych zajmujących się współpracą międzynarodową oraz materiały $z$ oficjalnego portalu internetowego Płocka.

Poniższa analiza wskazuje, że najintensywniejsze kontakty Płock utrzymuje z niemieckim miastem Darmstadt. Potwierdza to ogólnopolską tendencję, według której Niemcy są krajem, z którego samorządami terytorialnymi najliczniej i najbardziej wszechstronnie współpracują polskie samorządy terytorialne (Faliński, 2012). 
Współpraca Płocka z miastami w państwach postkomunistycznych - wliczając w to Chiny - ma charakter przede wszystkim formalno-instytucjonalny i opiera się głównie na kontaktach przedstawicieli władzy lokalnej, a w mniejszym stopniu na bezpośrednich kontaktach obywateli i grup obywatelskich (Huaian, Loznica, Możejki, Mytiszczi, Nowopołock, Plewen, Rustawi).

Zupełnie inaczej wygląda to w przypadku samorządów terytorialnych z Europy Zachodniej i Stanów Zjednoczonych, w których społeczeństwo obywatelskie jest rozwinięte, a demokracja ugruntowana. Tutaj współpraca formalno-instytucjonalna została w miarę rozwoju zdominowana przez kooperację obywatelską, która polega na współdziałaniu rozmaitych grup i instytucji społecznych składających się na społeczności miejskie - dzieci i młodzież, grupy zawodowe, środowiskowe, stowarzyszenia, zespoły artystyczne, kluby sportowe, ośrodki kultury, szkoły podstawowe, średnie czy wyższe.

Te składające się na społeczności lokalne mikrośrodowiska współpracują ze sobą bezpośrednio, nie potrzebując pozwolenia czy też pośrednictwa przedstawicieli władzy lokalnej, która działa wobec nich subsydiarnie - nie dominuje, a wspomaga (Auxerre, Darmstadt, Ford Wayne, Forli, Thurrock). W tym kierunku ewoluują także kontakty Płocka z miastami z państw postkomunistycznych, ale dzisiaj należących - jak Polska - do Unii Europejskiej i NATO (Możejki, Plewen).

Współpraca partnerska silnie powiązana jest z kontaktami z Polonią. Została ona w ogóle nawiązana ze względu na chęć wspomagania rodaków. Taki właśnie jest charakter współpracy z Bielcami i Żytomierzem. W obu tych przypadkach rozwinęła się współpraca obywatelska, podobnie jak odbywa się to w kooperacji z miastami zachodnimi. Nie wynika to z obywatelskiego charakteru obu tych społeczności lokalnych, lecz z poczucia więzi narodowej Polaków zamieszkujących w Płocku z mieszkańcami obu tych miast, którzy poczuwają się do historyczno-świadomościowej wspólnotowości z Polską i polskością.

Stosunkowo prosta jest odpowiedź na pytanie o genezę i ewolucję kontaktów międzynarodowych Płocka. Wydaje się, że o tym, z którymi zagranicznymi miastami Płock nawiązywał współpracę i z którymi ją kontynuował, decydował przypadek i w niejasny sposób określone preferencje rządzących tym miastem w konkretnym czasie miejskich elit politycznych. Ponadto rozwój tych kontaktów odbywał się w powiązaniu z polityką zagraniczną państwa polskiego, w związku z sentymentami narodowymi (współpraca z ośrodkami polonijnymi) czy też w nawiązaniu do specyfiki społeczno-gospodarczej Płocka.

Duża aktywność Płocka na arenie międzynarodowej jest związana z tym, że władze tego miasta przez wiele kadencji zabiegały i zabiegają o widoczną obecność swojego miasta w środowisku międzynarodowym. Dlatego utrzymywały bliskie kontakty 
z Ministerstwem Spraw Zagranicznych i współuczestniczyły w organizowanych przez nie przedsięwzięciach, promujących Polskę i Płock za granicą. Dzięki pośrednictwu MSZ zawarto kilka porozumień.

\section{Tradycje współpracy}

Tradycje współpracy międzynarodowej Płocka sięgają lat 60. ubiegłego wieku. W 1968 roku Szkole Podstawowej nr 1 w Płocku nadano imię znanego serbskiego etnografa, językoznawcy i historyka Vuko Karadżića (Bartuś, 2019: 2). Miała to być zapowiedź późniejszego zawarcia umowy o współpracy między dwoma miastami. Nastąpiło to w formie wstępnego porozumienia, które funkcjonowało przez pięć lat. Dotyczyło ono współpracy kulturalnej, polegającej na wzajemnej wymianie zespołów folklorystycznych i prezentacji sztuki ludowej, publikowania w lokalnych mediach materiałów dotyczących obu miast i najważniejszych świąt państwowych Polskiej Rzeczypospolitej Ludowej, czyli Święta Odrodzenia Polski 22 lipca, oraz Dnia Republiki Jugosławii 29 listopada, podjęcia działań mających na celu rozpoczęcie nauki języka polskiego w Lożnicy i serbsko-chorwackiego w Płocku, rozpoczęcia wymiany kolonijnej dzieci, a także wymiany stażowej po jednym lekarzu z każdej strony. W umowie tej zapowiadano - po podpisaniu kolejnych porozumień - rozszerzenie współpracy dotyczącej sportu, weterynarii, produkcji rolnej, budownictwa mieszkaniowego i wymiany młodzieży licealnej oraz innych, niedoprecyzowanych dziedzin życia społecznego.

Kolejne umowy o współpracy także miały charakter okresowy, podpisano je na lata 1977-1980, 1982-1985, 1986-1990. Na ich podstawie prowadzono wymiany grup dzieci i młodzieży, zespołów folklorystycznych oraz naukę języków. Wzajemnie odwiedzały się delegacje władz miejskich i grupy robocze zajmujące się problematyką gospodarki komunalnej, zagospodarowaniem przestrzennym, urbanistyką, architekturą, budownictwem mieszkaniowym, ochroną środowiska naturalnego, wykorzystywaniem zasobów i energii, infrastrukturą społeczną i techniczną, a także ochroną zabytków. Współpraca ta trwała do załamania się systemu komunistycznego, a uległa zupełnemu zawieszeniu podczas wojny domowej w dawnej Jugosławii.

Charakterystyczną cechą tej współpracy był fakt, że była ona elementem polityki zagranicznej realizowanej przez oba państwa, a podpisywane umowy zawierały zapis mówiący o tym, że wejdą one w życie po zaakceptowaniu przez odpowiednie - to znaczy państwowe i partyjne, czyli komunistyczne - władze. Taka była specyfika najpierw totalitarnych, a później - w przypadku Polski po przełomie październikowym 1956 roku - autorytarnych państw komunistycznych, w których samorząd 
terytorialny jako instytucja życia społeczno-politycznego nie istniał. Władze miejskie były wówczas elementem jednolitej i zhierarchizowanej, państwowej struktury administracyjnej (Loznica (porozumienie...); Wstępne porozumienie...).

\section{Płock - Darmstadt}

Kolejne porozumienie międzynarodowe Płocka pochodzi z okresu schyłku Polskiej Rzeczypospolitej Ludowej. Umowę podpisano 24 września 1988 r. z liczącym ponad 140 tysięcy mieszkańców Darmstadtem, niemieckim miastem leżącym w Hesji, w którym od 1980 r. działał Niemiecki Instytut Kultury Polskiej (Deutsches-Polen Institut).

Umowa partnerska została podpisana z inicjatywy Niemców. Warto zaznaczyć, że władze Darmstadtu miały już wcześniej podpisane sześć międzynarodowych umów partnerskich. W Polsce szukały partnera poprzez ambasady PRL. Równolegle o ustanowienie współpracy pomiędzy miastami zabiegał - najpierw niezależnie - profesor Georg Strobl z Wyższej Szkoły Technicznej w Darmstadcie, współpracownik mającej filię w Płocku Politechniki Warszawskiej. Na taki dobór miast partnerskich istotny wpływ miało też to, że oba dysponowały i dysponują wieloma secesyjnymi zabytkami (Bartuś, 2019: 1).

Sama umowa jest charakterystyczna dla czasu, w którym została podpisana, i świadczy o ścisłym wiązaniu ówczesnych kontaktów partnerskich pomiędzy miastami w Polsce Ludowej z polityką zagraniczną realizowaną przez instytucje rządowe i państwowe. Porozumienie to miało stanowić część składową normalizacji stosunków ówczesnej Polski z Republiką Federalną Niemiec. Dokument ten wręcz przywoływał układ o podstawie normalizacji stosunków wzajemnych pomiędzy PRL a RFN z 7 grudnia 1970 r. (Porozumienie o partnerskiej współpracy...).

W omawianym porozumieniu partnerskim znajdujemy względnie jasno określone dziedziny współpracy pomiędzy umawiającymi się stronami oraz formy, w jakich ta współpraca miała się realizować. Najogólniej mówiąc, dotyczyć miała ona wszelkich problemów komunalnych i rozwojowych obu miast ze szczególnym położeniem akcentów na problematykę kulturalną i społeczno-gospodarczą. Sfera kultury została w tym dokumencie uwypuklona (m.in. przedstawienia teatralne, przedsięwzięcia muzealnicze, wymiana i wystawianie prac plastycznych i fotografii, współpraca w dziedzinie muzyki). Podkreślono także znaczenie wymiany sportowej i turystycznej mającej na celu zawieranie bezpośrednich kontaktów pomiędzy obywatelami obu miast.

Okazją do takich spotkań i wzajemnego poznawania się mieszkańców, a także prezentacji dorobku różnych grup i instytucji społecznych składających się na społeczności 
lokalne Płocka i Darmstadtu, miały być okresowe imprezy przedstawiające życie kulturalne, naukowe i gospodarcze obu miast.

Zapoczątkowana w 1988 r. współpraca partnerska rozwijała się intensywnie przez lata i trwa, stanowiąc kluczową formę aktywności międzynarodowej historycznej stolicy Mazowsza. Wydaje się, że spośród wszystkich 14 umów o współpracy międzynarodowej, które Płock zawarł, ta pierwsza jest ciągle najważniejsza.

Początkowo podstawowe, oficjalne kontakty władz miejskich stały się z czasem bardzo istotną, ale tylko jedną z wielu form relacji obu wspólnot miejskich. Dominują kontakty obywatelskie określane przez współpracujące ze sobą różnego rodzaju instytucje, środowiska i grupy społeczne, porozumiewające się ze sobą niejako poza czy równolegle z władzami politycznymi, które to władze współpracę miast zapoczątkowały, zinstytucjonalizowały i współorganizują. Nie zawłaszczają one jednak pól kooperacji obywatelskiej, tylko działają w stosunku do płockiego fragmentu społeczeństwa obywatelskiego w sposób subsydiarny. Owocuje to dużą aktywnością społeczną i wielopłaszczyznową, obywatelską współpracą międzynarodową członków obu społeczności.

Obywatelski charakter współpracy międzynarodowej społeczności płocczan i mieszkańców Darmstadtu w większości określany jest przez działalność takich instytucji kultury jak muzea, galerie sztuki, biblioteki, teatry, szkoły i zespoły muzyczne (jazzowe, rockowe), orkiestry, zespoły folklorystyczne czy szkoły powszechne. Swój udział w tej współpracy mają także towarzystwa, stowarzyszenia i kluby sportowe, zajmujące się różnego rodzaju dyscyplinami - poczynając od szachów, poprzez lekką atletykę, piłkę nożną czy badminton, na kajakarstwie kończąc. Współpracują ze sobą również działające w Płocku i Darmstadcie przedstawiciele instytucji mających charakter ogólnopaństwowy, takich jak policja, straż pożarna, zakłady karne czy Polski oraz Niemiecki Czerwony Krzyż (www.plock.eu/pl/darmstadt_niemcy.html - 05.04.2019).

We współpracę Płocka i Darmstadt szczególnie zaangażowanych jest kilka ośrodków. Jako pierwszy należy wymienić Deutsches-Polen Institut (Niemiecki Instytut Kultury Polskiej), założony przez profesora Karla Dedeciusa, który działa od $1980 \mathrm{r}$. w Darmstadcie. Propagował on kulturę polską w Niemczech jeszcze przed 1988 rokiem, czyli rokiem podpisania umowy o współpracy między oboma miastami. Miał udział w doprowadzeniu do powstania partnerstwa miast. To właśnie ten instytut organizował w latach 90. ubiegłego wieku dyskusje panelowe z udziałem najważniejszych polskich i niemieckich polityków, na temat stosunków polsko-niemieckich, w których uczestniczyli także przedstawiciele Płocka jako jednego z miast zaangażowanych w budowanie dobrych relacji pomiędzy naszymi państwami i narodami.

W Płocku natomiast prowadzi swoją działalność Dom Darmstadt. Ta miejska placówka kulturalno-oświatowa organizacyjnie jest fragmentem Płockiego Ośrodka Kultury i Sztuki (zabytkowy budynek tej instytucji przebudowany został ze środków 
niemieckich). To tutaj odbywają się różnego rodzaju spotkania, koncerty, wykłady, odczyty, wystawy i imprezy kulturalne organizowane z udziałem ludzi kultury i sztuki oraz mediów i nauki z Darmstadtu i całych Niemiec, ale nie tylko. Generalnie działalność Domu Darmstadtu jest ukierunkowana na promowanie kultury i języka niemieckiego (bogata biblioteka niemieckojęzyczna), ale także na współpracę międzynarodową w ogóle, w ramach której odbywają się tutaj wydarzenia kulturalne z udziałem innych zagranicznych partnerów Płocka. Oczywiście dominują wydarzenia i działania dotyczące Darmstadtu, Hesji i Niemiec.

Prowadzona przez oba miasta współpraca międzynarodowa ma swój spektakularny wyraz w corocznych imprezach, na które składają się wydarzenia tak plenerowe, jak też te mniej masowe, następujące w salach koncertowych czy bibliotekach. Uczestniczą w nich nie tylko przedstawiciele Płocka i Darmstadtu, ale także reprezentanci innych, zaprzyjaźnionych z polskim i niemieckim miastem, wspólnot lokalnych. Od końca lat 90. ubiegłego wieku corocznie w maju odbywa się w Płocku Piknik Europy będący świętem naszego kontynentu, ale przede wszystkim przedsięwzięciem mającym umożliwić spotkanie się przedstawicieli związanych z Płockiem miast partnerskich, wśród których pierwszoplanową rolę odgrywa Darmstadt.

Po stronie polskiej istotnym przedsięwzięciem jest Festiwal Muzyki Elektronicznej ASTIGMATIC. Po stronie niemieckiej jest ich więcej. Są to obozy młodzieżowe, w których uczestniczy młodzież z Płocka, Międzynarodowy Konkurs Fryzjerski, Targi Turystyczne „Reisen, Caravan, Garten”. W obchodzonym corocznie w Darmstadcie święcie miasta Heinerfest, podobnie jak w Jarmarku Bożonarodzeniowym, biorą udział przedstawiciele różnych płockich środowisk społecznych.

Cechą charakterystyczną współpracy Płocka i Darmstadtu jest jej ewolucja od kontaktów oficjalnych władz do kontaktów obywatelskich. Zaangażowały się w nią różne grupy społeczne i środowiska. Współpracę podjęli przedstawiciele środowiska służby zdrowia z odpowiednikami z Darmstadtu. Kilkanaście pielęgniarek i kilku lekarzy wyjechało tam na staże i do pracy. Występy gościnne odbyła także grupa aktorów z płockiego teatru. Polskie studentki wyjechały na praktyki do Uniwersytetu Technicznego w Darmstadcie. Intensywny rozwój tej współpracy nastąpił jednak dopiero po roku 2000. Malarze z Darmstadtu uczestniczyli w polskich plenerach malarskich. Współpracowała Straż Pożarna z obu miast i ich okolic. Poeci publikowali wspólne tomiki wierszy. Wspólna aktywność objęła także środowiska malarzy i fotografików, współpraca trwa do dzisiaj.

We wzajemną wymianę zaangażowani są sportowcy i organizatorzy turystyki z obu miast. Szczególnie bliska współpraca dotyczy szachistów. Spotykają się na turniejach organizowanych w Darmstadcie i w Płocku. Bywają u siebie młodzi piłkarze, biathloniści, badmintoniści czy kajakarze. Polscy biegacze uczestniczą w niemieckich 
biegach maratońskich, a Płock jest odwiedzany przez rowerzystów z Hesji. Za szczególnie cenne uznawane są kontakty oraz współpraca dzieci i młodzieży. Parami współpracują ze sobą szkoły średnie, kontaktują się bezpośrednio i współpracują systematycznie w sposób względnie trwały.

\section{Płock - Fort Wayne}

Z kolejnym zagranicznym partnerem Płock związał się w okresie polskiego przełomu demokratycznego w 1990 r. Było to miasto Fort Wayne w stanie Indiana w USA (Fort Wayne...). Ówczesny senator Andrzej Celiński był akuszerem tego dwustronnego porozumienia (The City of Fort Wayne...). Nie rozwinęło się ono tak szeroko jak to z Darmstadtem, co można tłumaczyć różnicą w odległości Płocka od obu tych zaprzyjaźnionych miast, chociaż realizacja porozumienia z Fort Wayne trwa nieprzerwanie i dotyczy różnych sfer życia społecznego obu miast. Początkowo sprowadzała się ona do współpracy ekspertów i prezentacji amerykańskich rozwiązań dotyczących decentralizacji władzy publicznej oraz doradztwa stronie polskiej.

Później w tego typu prace zaangażowało się inne miasto partnerskie, tym razem była to japońska Takaoka. Powstała współpraca trójstronna, polegająca na wymianie i porównywaniu rozwiązań stosowanych w trzech miastach. W latach 90. ubiegłego wieku rozpoczęła się także współpraca w dziedzinie kultury. Kontaktom tym towarzyszyły spotkania i wzajemne wizyty przedstawicieli władz oraz społeczności obu miast, do których dochodziło podczas organizowanego w Płocku od 1999 roku Pikniku Europejskiego. Równolegle z kontaktami przedstawicieli instytucji władzy publicznej rozwijały się, aby z czasem zacząć dominować, kontakty natury obywatelskiej, takie jak Letnie Warsztaty Języka Angielskiego prowadzone przez nauczycieli z Fort Wayne.

W USA koncertował Harcerski Zespół Pieśni i Tańca „Dzieci Płocka”, a jedna z młodych płocczanek - Marika Michalska - uczestniczyła z sukcesem w amerykańskim konkursie młodych talentów. Jako jedyna Europejka została laureatką tego konkursu. W USA prace przedstawiali plastycy, fotograficy. Analogiczne wystawy amerykańskich przedstawicieli tego środowiska były eksponowane w Polsce.

\section{Płock - Wschód}

Partnerem Płocka są także Możejki, miasto położone w północnej Litwie, przy granicy z Łotwą, liczące nieco ponad 40 tysięcy mieszkańców. Oba miasta łączy to, że mieszczą się w nich rafinerie ropy naftowej. Umowę o współpracy podpisano 
23 czerwca 1994 r. (Porozumienie o partnerskiej współpracy między miastem Płock a Rejonem Możeikai...). Partnerstwo dotyczy problematyki zarządzania komunalnego, kultury i sportu. Cechą wyróżniającą tę współpracę jest zaangażowanie w nią względnie wielu środowisk i zespołów ludowych, uczestniczących w festiwalach i wzajemnych wymianach.

Muzeum Mazowieckie w Płocku organizuje w Możejkach wystawy popularyzujące sztukę ludową Mazowsza i prezentujące Litwinom bardzo cenne zbiory secesji. Bibliotekarze płoccy upowszechniają u naszego sąsiada polskie książki, organizując takie wydarzenia jak Tydzień Książki Polskiej, okolicznościowe wystawy czy międzynarodowe konferencje poświęcone bibliotekarstwu. Oczywiście okazją do wspólnych spotkań są organizowane w obu miastach wydarzenia kulturalno-sportowe, których celem są właśnie wzajemne poznawanie się oraz prezentowanie swojego charakteru, dorobku i kultury przez wszystkie zaprzyjaźnione i z Płockiem, i z Możejkami miasta.

Kolejny partner międzynarodowy historycznej stolicy Mazowsza to białoruski, liczący ponad 160 tysięcy mieszkańców, Nowopołock, w którym podobnie jak w Możejkach istnieje duży kombinat rafineryjno-petrochemiczny. Płock nawiązał ten kontakt za pośrednictwem polskiej ambasady w Mińsku, a porozumienie o współpracy partnerskiej, poprzedzone wcześniejszymi, wzajemnymi wizytami przedstawicieli władz miejskich, podpisano 29 maja 1996 roku.

Współpraca z tym partnerem dotyczy przede wszystkim sfery sportu i kultury. Można ją podzielić na dwa okresy. Pierwszy - do 2005 roku, kiedy prezydent Płocka Mirosław Milewski zawiesił wzajemne kontakty ze względu na nierespektowanie na Białorusi praw człowieka i zaostrzenie stosunków polsko-białoruskich. Do tego roku oficjalne delegacje uczestniczyły w organizowanych w obu miastach festynach i świętach municypalnych. Stroną częściej odwiedzającą partnera była strona białoruska, której reprezentanci regularnie uczestniczyli najpierw w Dniach Miast Partnerskich, a następnie Pikniku Europejskim (od jego powołania do życia w 1999 roku). Prawidłowość ta dotyczy nie tylko władz miasta, ale także sportowców - lekkoatletów, piłkarzy czy młodzieży szkolnej, której reprezentanci wzięli udział w Międzynarodowych Igrzyskach Młodzieży Szkolnej Płock 2002.

W tym samym roku oba miasta uczestniczyły w Brześciu w spotkaniu miast partnerskich z Polski i Białorusi. Drugi okres współpracy zaczął się w roku 2012, kiedy prezydent Płocka Andrzej Nowakowski zdecydował o wznowieniu kontaktów. W roku 2014 przedstawiciele obu miast wzięli udział w kolejnym spotkaniu miast partnerskich, które tym razem zorganizowano w Białymstoku. W tym samym roku z Nowopołocka przyjechał na koncerty dziecięcy chór Clear Voices Choir, który koncertował w płockiej katedrze w ramach Festiwalu Płockie Dni Muzyki Chóralnej. Dwa 
lata później w Płocku gościł i występował zespół „Komariki”, zaproszony na obchody 70-lecia Harcerskiego Zespołu Pieśni i Tańca „Dzieci Płocka”. W kolejnych latach odwiedzały się podczas swoich miejskich świąt oficjalne delegacje. Wydaje się, że ta forma wzajemnych kontaktów w relacjach Płocka z Nowopołockiem dominuje i podobnie lub nawet $\mathrm{w}$ większym stopniu niż w relacjach z Możejkami, ma charakter głównie instytucjonalny, a obywatelski tylko w ograniczonym zakresie (Opis współpracy Płock - Nowopołock...).

Kolejnym partnerem Płocka (od września 2000 roku) jest mołdawskie miasto Bielce liczące ponad 160 tys. mieszkańców. Porozumienie ma odmienną od poprzednich specyfikę. Bardzo istotną część współpracy stanowi bowiem współpraca z tamtejszą społecznością polską liczącą ok. 700 osób, skupioną w stowarzyszeniu Dom Polski. Zajmuje się on utrzymywaniem i pielęgnowaniem polskości. Kontakty stały się intensywne i wielostronne. Płock był i jest bardzo zaangażowany w pomoc humanitarną dla Bielc i ich mieszkańców. Organizowano zbiórki odzieży i sprzętu medycznego dla tamtejszej służby zdrowia, której przedstawiciele odbywali staże w Polsce. Instytucją, która organizuje ze strony mołdawskiej tę współpracę, jest działające w Bielcach Polskie Towarzystwo Medyczne.

Tradycyjnie silną sferą współpracy jest sport - piłka nożna, judo czy lekka atletyka. Znaczenie ma także problematyka kultury, w tym przypadku przede wszystkim kultura Polonii mołdawskiej. Jej przedstawiciele odwiedzali Płock wielokrotnie, głównie podczas Pikniku Europejskiego. We współpracę szczególnie zaangażowani są płoccy harcerze czy dzieci z Galerii Sztuki Dzieci i Młodzieży Płockiego Ośrodka Kultury i Sztuki.

Polskie miasto odwiedzają dość często związani z Bielcami i Mołdawią przedsiębiorcy, dziennikarze i przedstawiciele mediów. Okazją do spotkań jest zwykle Jarmark Europejski, podczas którego towarzyszą przedstawicielom władz Bielc.

Kolejna umowa partnerska Płocka została podpisana dzięki aktywności międzynarodowej marszałka województwa mazowieckiego. W kwietniu 2003 r. prezydent Płocka - towarzysząc mu - złożył wizytę w rosyjskim Smoleńsku i mieście Mytiszczi. Celem tego wyjazdu było znalezienie rosyjskiego miasta partnerskiego.

Po tej wizycie władze Mytiszczi zaprosiły delegację Płocka na uroczyste obchody 380-lecia ich miasta w 2003 r. Podpisano wówczas wstępne porozumienie o współpracy. Nastąpiły kolejne wizyty płocczan. W 2005 r. najpierw młodzież wzięła udział w obozie letnim ze swoimi rówieśnikami z Rosji, Ukrainy, Białorusi i Litwy, a później delegacja władz miejskich uczestniczyła w spotkaniu miast partnerskich Mytiszczi z Białorusi, Bułgarii, Czech, Litwy, Ukrainy i Włoch.

W następnym roku Rosjanie wzięli udział w Pikniku Europejskim, przywieźli m.in. zespół taneczny, przedstawicieli środowiska biznesowego. W 2006 r. podpi- 
sano ostateczną umowę o współpracy partnerskiej. Doszło do wymiany młodzieży, wspólnych imprez sportowych. W następnych latach współpraca obu miast rozwijała się i trwa do dzisiaj jako jedna $\mathrm{z}$ intensywniejszych. Spotkania następują podczas cyklicznych imprez organizowanych w obu miastach.

Bułgaria to kolejny kierunek kontaktów międzynarodowych Płocka. Władze miasta zawarły porozumienie z miastem Plewen, które liczy ponad 100 tys. mieszkańców, a leży w północnej części kraju. Pośrednikiem była ambasada polska w Sofii. Delegacje Plewen przyjechały na Piknik Europejski w latach 2010 i 2011, zaś w roku 2011 delegacja Płocka wzięła udział w obchodach Dni Plewen. Umowę podpisano 7 września 2011 r. (Umowa o współpracy partnerskiej podpisana w Płocku 7 września 2011 roku...).

Współpraca dotyczy, poza kulturą, sportu oraz - co stanowi nowość - pomocy społecznej, w której aktywny jest płocki Miejski Ośrodek Pomocy Społecznej. Goszczący w Płocku Bułgarzy biorą udział nie tylko w Pikniku Europejskim, ale także $\mathrm{w}$ innych płockich wydarzeniach plenerowych. Specyfiką realizowania tego partnerstwa są relacje studentów i władz dwóch publicznych uczelni: Państwowej Wyższej Szkoły Zawodowej w Płocku i Uniwersytetu Medycznego w Plewen, które współpracują w ramach europejskiego programu Erasmus. W obustronnej wymianie uczestniczą studenci i wykładowcy (Współpraca z miastem Plewen...).

Kolejnym partnerem Płocka jest ukraiński Żytomierz liczący ok. 300 tys. mieszkańców. Współpracę nawiązano w 2013 r. za pośrednictwem Konsulatu Generalnego RP w Łucku. Przedstawiciele tego poleskiego miasta biorą udział w Pikniku Europejskim oraz różnego rodzaju turniejach i zawodach sportowych. Środowiskiem szczególnie - poza władzami obu miast - zaangażowanym w organizowanie tej współpracy jest poleska Polonia.

Płoccy harcerze organizują pomoc dla mieszkujących na Polesiu rodaków, przygotowują paczki dla najbardziej potrzebujących, a młodzież szkolna zbiera materiały, książki i sprzęt elektroniczny do nauki języka polskiego.

Władze Płocka zawarły również umowę z gruzińskim Rustawi, z inicjatywy ambasadora Gruzji w Polsce. Współpraca była bezpośrednio powiązana z projektem Partnerstwa Wschodniego i w tym zakresie współpraca obu miast miała być finansowana przez Ministerstwo Spraw Zagranicznych w ramach zadania „Polska Pomoc Rozwojowa" (nie doszło do tego finansowania).

Władze Płocka sięgnęły poza Europę. W 2010 r. umowę o współpracy podpisały z chińskim Huai’an. Ma ona jednak bardziej powierzchowny charakter, ogranicza się do współpracy miejskich struktur władzy publicznej, a nie obejmuje społeczności lokalnych. W umowie znajdujemy znamienny zapis: „Umawiające się strony zobowiązują się utrzymywać stały kontakt między osobami sprawującymi władzę oraz 
odpowiednimi wydziałami w celu ułatwienia wzajemnych konsultacji w sprawie wymiany i współpracy, a także bieżących wspólnych spraw" (Umowa o współpracy partnerskiej zawarta w Płocku dnia 8 lipca 2010 roku...).

Rzeczywiście współpraca nie przeszła na poziom obywatelski. Mimo to kontakty są stale utrzymywane. Delegacje obu miast regularnie u siebie bywają, a towarzyszą im przedstawiciele biznesu (Informacja na temat współpracy z miastem Huaian...).

\section{Płock - Zachód}

23 maja 1998 r. Płock zawarł umowę o współpracy z włoskim, liczącym ok. 110 tysięcy obywateli Forli, z którym blisko współpracował już wcześniej (zgodnie z mającą charakter wstępny, a podpisaną 3 kwietnia 1993 r. Deklaracją o Współpracy Partnerskiej). W dokumencie z 1998 roku znajdujemy treści i sformułowania niespotykane we wcześniejszych porozumieniach międzynarodowych podpisanych przez władze Płocka.

W umowie tej pisze się wprost o porozumieniu bliźniaczym, czyli powstałej na początku lat 50. ubiegłego wieku formie współpracy miast europejskich oraz odwołuje się bezpośrednio do wspólnoty kulturowo-cywilizacyjnej Europy, jej państw i miast, pisząc: „Miasta Forli i Płock mają świadomość, iż najlepszą gwarancją umocnienia pokoju i współżycia obywatelskiego stanowi szeroko pojęta integracja europejska i promocja idei Wspólnej Europy. Kontynent nasz pomimo różnic historycznych, kulturowych i instytucjonalnych, stanie się wówczas rzeczywistością już nie podzieloną i przeciwstawną, ale solidarną i współpracującą" (Umowa o utworzeniu miast bliźniaczych Forli - Płock).

Po podpisaniu tej umowy współpraca pomiędzy Forli i Płockiem rozwijała się w tym duchu bardzo intensywnie. Nie sprowadzała się przede wszystkim do wymiany oficjalnych delegacji obu miast, ale znajdowała się na poziomie obywatelskim. Kooperowały ze sobą organizacje społeczeństwa obywatelskiego oraz współpracowali sami obywatele.

Utrzymywali ze sobą kontakty sportowcy w różnym wieku i uprawiający różne dyscypliny: piłkarze, lekkoatleci, judocy (Międzynarodowy Turniej Judo w Forli) czy tradycyjnie już zaangażowani w kontakty międzynarodowe szachiści. Reprezentacja młodych sportowców z Forli wzięła udział w 34. Międzynarodowych Igrzyskach Szkolnych Płock 2002.

Tak owocna współpraca Płocka z Forli kilka lat temu uległa praktycznie zamrożeniu. Prezydent Płocka wskazuje umowę z Forli jako jedną z umów „martwych”, a współpracę jako zawieszoną. Nie wyjaśnia jednak przyczyn takiego stanu rzeczy 
(wywiad S. Falińskiego z prezydentem Płocka Andrzejem Nowakowskim przeprowadzony 7.02.2019).

Władze Płocka zawarły partnerskie porozumienie również z miastem Auxerre, leżącym w Burgundii, liczącym oko. 40 tys. mieszkańców. Umowy podpisywano w 1998 r. i w 2000 r. Zawierają kierunkowe określenie charakteru współpracy, nie tylko - co typowe dla tego typu porozumień - poprzez określenie jej dziedzin (kultura, nauka, turystyka, oświata, ochrona środowiska, gospodarka czy działalność samorządowa), ale także, czy przede wszystkim, poprzez jednoznaczne zapisanie dążenia do doprowadzenia do bezpośredniej współpracy struktur charakterystycznych dla aktywnego społeczeństwa obywatelskiego: stowarzyszeń, fundacji, organizacji społecznych i instytucji kultury i oświaty.

Wskazuje to na chęć świadomego budowania więzi społecznych pomiędzy obiema wspólnotami miejskimi oraz traktowania instytucji władzy publicznej jako działających w stosunku do tych więzi subsydiarnie, a także aktywizowania lokalnych wspólnot samorządowych w sferze kontaktów międzynarodowych.

Sferą szczególnej aktywności jest współpraca szkół licealnych. Przyjeżdżali do Polski młodzi Francuzi, którzy poznawali nasze gospodarstwa rolne i agroturystyczne oraz różnego rodzaju przedsiębiorstwa sektora rolno-spożywczego. Liceum Ogólnokształcące im. Stanisława Małachowskiego zaprzyjaźnione jest z Zespołem Szkół Saint-Joseph La Salle. Odwiedzają się także studenci kierunków ekonomicznych uczelni wyższych z obu miast. Współpracują ze sobą placówki kulturalne - domy kultury, galerie, a artyści bywają u siebie, prezentując swoje prace malarskie, rzeźbiarskie i fotograficzne.

Odwiedzają się także młodzi sportowcy: judocy i piłkarze uczestniczący w różnego rodzaju turniejach i zawodach organizowanych w ramach cyklicznych imprez kulturalnych czy sportowych, takich jak płocki Piknik Europejski i francuskie Targi Kultury Regionalnej „Auxerrexpo”.

Swoistą nowością w tej współpracy są kontakty środowisk ludzi starszych, np. z Uniwersytetu Trzeciego Wieku, z mieszkańcami Auxerre. Kontakty te wspomagają organizowane w Domu Darmstadt kursy języka francuskiego czy okazjonalnie organizowane w Burgundii kursy języka polskiego dla Francuzów, głównie mających polskie korzenie (Auxerre - Republika Francuska...).

Władze Płocka nawiązały także partnerstwo $\mathrm{z}$ angielską gminą Tharrock, liczącą ponad 140 tys. mieszkańców, leżącą przy ujściu Tamizy. Kontakt zadzierzgnięto za pośrednictwem Związku Miast Polskich (Bartuś, 2019: 1). W podpisanej 5 października 2004 r. umowie sfery współpracy określono analogicznie jak we wcześniejszej umowie z Auxerre. Podobnie także zobowiązano się do popierania rozwoju bezpośrednich kontaktów pomiędzy instytucjami społeczeństwa obywatelskiego w obu 
wspólnotach lokalnych (Umowa o współpracy partnerskiej w dziedzinie kultury, nauki, oświaty, sportu, ochrony zdrowia, gospodarki oraz działalności samorządowej podpisana w Płocku dnia 5 października 2004 roku...). Początkowo współpraca polsko-angielska układała się dobrze.

Delegacja z Anglii wzięła udział w Pikniku Europejskim w 2005 roku. Przygotowano poświęconą prezentacji tej gminy wystawę „Tharroc - inne spojrzenie”. Zorganizowano specjalną konferencję poświęconą prezentacji możliwości gospodarczych Płocka i Tharrock, w której wzięli udział przedstawiciele środowisk biznesowych z obu miast. Podjęto także działania mające na celu współpracę płockich szkół podstawowych, gimnazjów oraz liceów. Niestety po początkowych deklaracjach, wstępnych spotkaniach i pracach przygotowawczych dotyczących oświaty, kultury i biznesu współpraca zamarła i obecnie praktycznie nie istnieje. Jest to druga „martwa” umowa partnerska Płocka (wywiad S. Falińskiego z prezydentem Płocka Andrzejem Nowakowskim przeprowadzony 7.02.2019).

\section{$* * *$}

Warto podkreślić na koniec, że aktywność Płocka na arenie międzynarodowej nie ogranicza się tylko do współpracy z miastami partnerskimi ${ }^{3}$. Dzięki kontaktom z Ministerstwem Spraw Zagranicznych miasto licznie odwiedzają przebywający w Polsce dyplomaci i ich rodziny. W 2002 roku gościło w Płocku 38 ambasadorów, w 2006 odwiedziło miasto 29 ambasadorów (udział w konferencji poświęconej promocji polskich samorządów terytorialnych).

Instytucje miejskie Płocka uczestniczą w międzynarodowych projektach Unii Europejskiej, m.in. w programie ADHOC - Rozwój Historycznych Starówek w Środkowej i Wschodniej Europie, kolejnym jest EuRob II - Instytucjonalizacja Europejskiego Szlaku Gotyku Ceglanego. W ramach innej Inicjatywy Wspólnotowej URBAN II Płock uczestniczy w programie URBAMAS - System Zarządzania Przestrzenią Miejską. Tradycje tej współpracy europejskiej sięgają jeszcze czasów sprzed akcesji Polski do Unii. Samorząd płocki uczestniczył w programie PHARE’97 - Integracja Europejska. W ramach programu „Town Twinning” korzystał ze środków Unii, organizując Piknik Europejski specjalnie, by stworzyć możliwość spotkania się z przedstawicielami zaprzyjaźnionych miast.

Współpraca międzynarodowa Płocka okazuje się na tyle bogata, że został uhonorowany za nią cennym nagrodami europejskimi mimo braku dokumentów programowych dotyczących kontaktów zagranicznych tego miasta na prawach powiatu.

3 Poza omówionymi miastami partnerskimi Płock przygotowuje podjęcie współpracy - jest podpisany list intencyjny - z mongolskim Bayanzurkh. Na wstępnym etapie są też rozmowy z węgierskim Veszprem. 
Na przykładzie Płocka możemy zaobserwować ewolucję charakteru współpracy międzynarodowej lokalnej wspólnoty samorządowej. Aktywność międzynarodowa władz miasta doprowadziła do aktywności w tym zakresie obywateli Płocka i instytucji społeczeństwa obywatelskiego. Współpracę rozpoczynają władze miejskie, a kontynuują i rozwijają szkoły, kluby sportowe, zespoły muzyczne i taneczne, instytucje kultury, różnego rodzaju towarzystwa i stowarzyszenia. Płocka wspólnota samorządowa osiągnęła w swojej działalności międzynarodowej etap obywatelski, który charakteryzuje się tym, że kontakty międzynarodowe utrzymują nie tylko lub nie przede wszystkim przedstawiciele administracji samorządowej, ale realizowane są one przez poszczególnych członków społeczności i organizacje obywatelskie. W ten sposób płocczanie poznają się i zaprzyjaźniają ze swoimi kolegami z innych miast. Tworzą się owocujące współpracą i sympatią międzynarodowe więzi społeczne, a nie tylko, jak w przypadku kontaktów ograniczonych do sprawujących władzę, więzi formalno-instytucjonalne - tyle łatwe do nawiązania co do rozwiązania. Inaczej to wygląda w przypadku więzi społecznych. Budowane są dłużej, ale są też względnie trwałe. Wydaje się, że w Płocku taka sytuacja dotyczy nie tylko instytucji, ale przede wszystkim wspólnoty samorządowej, czyli samych płocczan.

\section{Bibliografia}

Auxerre - Republika Francuska (projekt umowy o wspótpracy w dziedzinie kultury, nauki, oświaty, ochrony zdrowia i gospodarki, oraz działalności samorzadowej podpisano w Płocku dnia 25 maja 1998 roku. Umowę bliźniacza pomiędzy Auxerre i Płockiem podpisano 17 czerwca 2000 roku w Auxerre i 14 października w Płocku). Notatka służbowa w zasobach Urzędu Miasta Płocka.

Bartuś, D. (2019). Wspótpraca międzynarodowa Płocka. Opracowanie na podstawie pytań przygotowanych przez S. Falińskiego. Płock (na prawach maszynopisu).

Dolnicki, B. (2009). Samorzą terytorialny. Warszawa: Wolters Kluwer.

Faliński, S. (2011). Współpraca międzynarodowa samorządów terytorialnych, w: Wymiana $i$ konkurencja. Środowisko i formy promocji Polski w świecie. Studia i Analizy Dyplomacji Kulturalnej i Publicznej, 2. Warszawa: Collegium Civitas i Instytut Adama Mickiewicza.

Fuksiewicz, A., Łada, A., Wenerski, Ł. (2012). Współpraca zagraniczna polskich samorzadów. Wnioski z badań. Warszawa: Instytut Spraw Publicznych.

Fort Wayne - Plock sister cities agreement. Archiwum Zakładowe Urzędu Miasta Płocka.

Jarosz, A. (2017). Powiat w Polsce na tle rozwiązań europejskich, w: Powiat w Polsce. Problemy i wyzwania szczebla ponadgminnego, A. Jarosz, B. Springer (red.), Zielona Góra, Oficyna Wydawnicza Uniwersytetu Zielonogórskiego: 183-206.

Informacja na temat wspótpracy $z$ miastem Huaian (Chiny). Notatka służbowa w zasobach Urzędu Miasta Płocka. 
Loznica w Jugosławii. Archiwum Zakładowe Urzędu Miasta Płocka.

Loznica (porozumienie o partnerskiej współpracy z 23 września 1972 roku, reaktywowanie umowy o współpracy - 13 maja 2001 roku). Notatka służbowa w zasobach Urzędu Miasta Płocka.

Ludność. Stan i struktura oraz ruch naturalny w przekroju terytorialnym w 2016 r. Stan $w$ dniu 31. XII (2017). Warszawa: Główny Urząd Statystyczny.

Mażeikiai (Możejki) - Litwa (porozumienie o partnerskiej współpracy z 23 czerwca 1994 r.). Notatka służbowa w zasobach Urzędu Miasta Płocka.

Machalski P. (2019). Współpraca międzynarodowa jednostek samorządu terytorialnego. Samorząd terytorialny w Unii Europejskiej, w: Samorząd terytorialny w systemie administracji publicznej, R. Gawłowski, P. Machalski, K. Makowski. Warszawa: CeDeWu.

Miasto Auxerre. Umowa bliźniacccza (pisownia oryginalna - Stanisław Faliński). Archiwum Zakładowe Urzędu Miasta Płocka.

Opis współpracy Płock-Nowopołock (porozumienie o współpracy partnerskiej z 29 maja 1996). Notatka służbowa w zasobach Urzędu Miasta Płocka.

POROZUMIENIE o partnerskiej wspótpracy między miastem Płock a miastem Darmstadt. Archiwum Zakładowe Urzędu Miasta Płocka.

Porozumienie o partnerskiej wspótpracy między miastem Płock i Rejonem Mażeikiai. Archiwum Zakładowe Urzędu Miasta Płocka.

Przebieg dotychczasowych kontaktów z miastem Żytomierz na Ukrainie. Notatka służbowa w zasobach Urzędu Miasta Płocka.

The City of Fort Wayne. Office of the Mayor. Proclamation. Archiwum Zakładowe Urzędu Miasta Płocka.

Umowa o współpracy partnerskiej podpisana w Płocku 7 września 2011 roku. Archiwum Zakładowe Urzędu Miasta Płocka.

Umowa o współpracy partnerskiej w dziedzinie kultury, nauki, oświaty, sportu, ochrony zdrowia, opieki społecznej, gospodarki oraz działalności samorzadowej, podpisana w Rustawi dnia 17 września 2016 roku. Archiwum Zakładowe Urzędu Miasta Płocka.

Umowa o współpracy partnerskiej $w$ dziedzinie kultury, nauki, oświaty, sportu, ochrony zdrowia, opieki społecznej, gospodarki oraz działalności samorządowej podpisana w Żytomierzu 12 października 2013 roku. Archiwum Zakładowe Urzędu Miasta Płocka.

Umowa o wspótpracy partnerskiej $w$ dziedzinie kultury, nauki, oświaty, sportu, ochrony zdrowia, gospodarki oraz działalności samorządowej podpisana w Płocku dnia 5 października 2004 roku. Archiwum Zakładowe Urzędu Miasta Płocka.

Umowa o współpracy partnerskiej w dziedzinie kultury, nauki, oświaty, sportu, gospodarki oraz działalności samorządowej podpisana w Płocku dnia 5 maja 2006 roku. Archiwum Zakładowe Urzędu Miasta Płocka.

Umowa o współpracy partnerskiej zawarta w Płocku dnia 8 lipca 2010 roku. Archiwum Zakładowe Urzędu Miasta Płocka.

Umowa o utworzeniu miast bliźniaczych Forli - Płock. Archiwum Zakładowe Urzędu Miasta Płocka. 
Umowa o współpracy w dziedzinie kultury, nauki, oświaty, sportu, ochrony zdrowia i gospodarki oraz działalności samorządowej podpisana w Bielcach dnia 14.11.2001 r. Archiwum Zakładowe Urzędu Miasta Płocka.

Współpraca FORT WAYNE - USA (7 marca 1990 - przyjęcie Płocka jako miasta partnerskiego przez Komitet Miast Siostrzanych Fort Wayne, 4 czerwca 1990 - podpisanie Proklamacji o współpracy partnerskiej). Notatka służbowa.

Współpraca międzynarodowa z Darmstadt (Republika Federalna Niemiec) - porozumienie o partnerskiej współpracy z dnia 24 września 1988 roku. Notatka służbowa w zasobach Urzędu Miasta Płocka.

Współpraca partnerska Płock - Bielce w latach 2000-2016. Notatka służbowa w zasobach Urzędu Miasta Płocka.

Współpraca partnerska samorządów. Praktyczny przewodnik (2009). Poznań: Związek Miast Polskich.

Współpraca z miastem Mytiszczi - Rosja. Notatka służbowa w zasobach Urzędu Miasta Płocka. Współpraca z miastem Plewen (Bułgaria). Notatka służbowa w zasobach Urzędu Miasta Płocka. Współpraca z Rustawi (Gruzja). Notatka służbowa w zasobach Urzędu Miasta Płocka.

Wstępne porozumienie w sprawie formy dalszej współpracy społeczno-kulturalnej między Prezydium Miejskiej Rady Narodowej w Płocku a Rada Miejska miasta Loznica w Jugosławii. Archiwum Zakładowe Urzędu Miasta Płocka.

Wywiad przeprowadzony przez S. Falińskiego z Dorotą Bartuś 19 lutego 2019 r.

Wywiad przeprowadzony przez S. Falińskiego z prezydentem Płocka Andrzejem Nowakowskim 7 lutego $2019 \mathrm{r}$.

Zybała, A. (2013). Państwo i społeczeństwo $w$ działaniu. Polityki publiczne wobec potrzeb modernizacji państwa i społeczeństwa. Warszawa: Difin.

\section{Źródła internetowe:}

www.plock.eu/pl/auxerre_francja.html

www.plock.eu/pl/bielce_moldowia.html

www.plock.eu/pl/darmastadt_niemcy.html

www.plock.eu/pl/forli_wlochy.html

www.plock.eu/pl/huaian_chiny.html

www.plock.eu/pl/miasta_partnerskie.html

www.plock.eu/pl/mozejki_litwa.html

www.plock.eu/pl/nowopolock_bielarus.html

www.plock.eu/pl/plewen_bulgaria.html

www.plock.eu/pl/rustawi_gruzja.html

www.plock.eu/pl/thurrock_wielka_brytania.html

www.plock.eu/pl/zytomierz_ukraina.html 